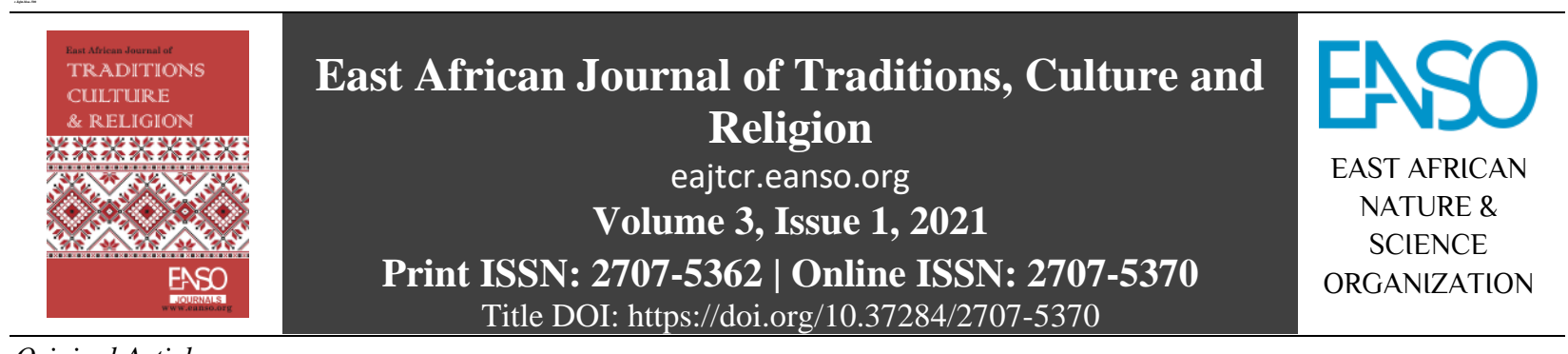

Original Article

\title{
Feminist Ethics and Gender Portrayals in Urhobo (African) Traditional Music.
}

\author{
Mark Omorovie Ikeke \\ ${ }^{1}$ Department of Religious Studies and Philosophy, Delta State University, PMB 1, Abraka, Nigeria. \\ Author Correspondence Email: Ikeke7@yahoo.com.
}

Article DOI: https://doi.org/10.37284/eajtcr.3.1.347

\section{Date Published: ABSTRACT}

22 June 2021 Essential concern of feminist ethics is that the moral perspectives and experiences of women are not often taken into cognizance in ethical discussion and that there is

Keywords: an unjust power structure in a culture that discriminates against women and privileges the position and rights of men over women. The moral ideal is often

Power Structure,

Male Evaluation,

Cultural Life,

Critical Analytic,

Positive Values,

Feminist Ethics. based on the male evaluation. The moral views on what ought to be just relationships between men and women permeate almost all aspects of cultural life, including music. Urhobo traditional music is not an exception. Urhobo traditional music which is a reflection of African traditional values that endorses patriarchy portrays women as inferior to men and women are to be subservient to men in decision-making in society. The paper will use critical analytic and hermeneutic methods to do a feminist ethical critique of gender portrayal in Urhobo traditional music. Excerpts from Urhobo traditional music will be presented, translated and their meaning evaluated. The paper finds and concludes that there is a need to create traditional music that projects the equality of men and women, just relationships among the sexes, and enhances the positive values of feminist ethics.

\section{APA CITATION}

Ikeke, M. O. (2021). Feminist Ethics and Gender Portrayals in Urhobo (African) Traditional Music. East African Journal of Traditions, Culture and Religion, 3(1), 1-10. https://doi.org/10.37284/eajtcr.3.1.347

\section{CHICAGO CITATION}

Ikeke, Mark Omorovie. 2021. "Feminist Ethics and Gender Portrayals in Urhobo (African) Traditional Music.". East African Journal of Traditions, Culture and Religion 3 (1), 1-10. https://doi.org/10.37284/eajtcr.3.1.347.

\section{HARVARD CITATION}

Ikeke, M. O. (2021) "Feminist Ethics and Gender Portrayals in Urhobo (African) Traditional Music.", East African Journal of Traditions, Culture and Religion, 3(1), pp. 1-10. doi: 10.37284/eajtcr 3.1.347.

\section{IEEE CITATION}

M. O. Ikeke, "Feminist Ethics and Gender Portrayals in Urhobo (African) Traditional Music.”, EAJTCR, vol. 3, no. 1, pp. 1-10 Jun. 2021.

1 | This work is licensed under a Creative Commons Attribution 4.0 International License. 


\section{MLA CITATION}

Ikeke, Mark Omorovie. "Feminist Ethics and Gender Portrayals in Urhobo (African) Traditional Music." East African Journal of Traditions, Culture and Religion, Vol. 3, no. 1, Jun. 2021, pp. 1-10, doi:10.37284/eajtcr.3.1.347.

\section{INTRODUCTION}

All over the world in many cultures, there are various images and pictures or portrayals of the place and role of both men and women in society. Some of the roles and places of men and women in society are not necessarily assigned by nature. They are human constructs and have survived from generation to generation. Some of the portrayals of the role and place of women and men in society are positive while others are negative. Many human cultures are patriarchal and have often subjugated women and children and seen them as inferior to men. Women are often perceived as weak, feeble, and to be confined to the kitchen or other domestic chores. These images pervade also in much of African cultures of which Urhobo is one of such cultures.

The negative perception of women and the consequent gender discrimination is an affront to feminist ethics. Feminist ethics does not argue for the superiority of women over men but rather affirms that both men and women are ontologically equal. Men and women may play different roles based on cultural constructs, but both of them need to be affirmed. Women's ways of knowing and being in the world need to be highlighted and promoted. Wherever negative images of women are portrayed, such as in some Urhobo music, they need to be reconstructed. The goal of this paper is to use the values of feminist ethics to critique Urhobo music. Not all Urhobo music has negative images of women. There are many songs in Urhobo music that have positive images of men and women. But that is not the concern of this paper.

Using critical analytic and hermeneutic methods, the paper will clarify the basic concepts that inform this work. It will break open the various concepts in order to understand them. Through critical argumentation, it will show that some Urhobo music needs to be reconstructed to promote gender justice and equality. Through the hermeneutic method, except from some Urhobo music will be presented, interpreted and their meaning and implications are drawn out. This paper proceeds in the following manner: (1) clarification of key concepts, (2) presentation of the challenge of feminist ethics, (3) presentation of gender portrayals in Urhobo traditional thought and culture, (4) gender portrayals in Urhobo traditional music, (5) rethinking and reconstructing gender portrayal in Urhobo traditional thoughts with feminist ethics, and (6) concluding reflections.

\section{Conceptual Clarifications}

Concepts that underlie this paper that will help in better understanding of the issues involved here are feminist, ethics, gender, portrayal, Urhobo, traditional, and music. Central to the feminist argument is that women and children have often been treated as inferior, discriminated against and deprived of some of their fundamental human rights by a male-dominated society. There is no monolithic definition of feminism rather the term is filled with nuances. There are radical feminists, ecofeminists, socialist feminists, black feminists, conservative feminists, post-feminists, liberal feminists, egalitarian feminists, difference feminists, womanists, etc. The concern of many of them is that women are denied power and suffer from unjust relationships. Johari (2012) avers that feminists are against the treatment of women as means of exchange, and they also argue against gender inequality and injustice. When it comes to the exercise of power and decision-making in society, women are often in a disadvantaged position. Ethics is acknowledged widely to be the study of the basis for human relationships in terms of rights and wrong. Various ethical theories conceive what is right or wrong differently. For feminists right and wrong is defined by how it affects the gender. Anything that promotes gender injustice, inequalities, subjugates women and children that portrayals them as inferior, weak, sinful, evil, etc is wrong and ought to be condemned.

Since gender justice and equality is a core concern of feminist ethics it is imperative to define gender. Menon (2008) describes gender as the "vast range of cultural meanings attached to the basic difference" between men and women (p. 225). The differences here refer to biological differences.

2 | This work is licensed under a Creative Commons Attribution 4.0 International License. 
Menon (2008) notes that it is important to recognize this because in both philosophical writings and culture these biological differences have been fundamentally used to perpetuate oppression against women. This biological determinism as it has come to be known is against feminists values. The roles and functions assigned to men and women are cultural constructs and vary from society to society. What is feminine in one culture may be masculine in another culture. The socialization of boys and girls in different cultures is different. These differences should not be used to subjugate women or deny them prominent leadership positions in society. Portrayal refers to the way things are seen or perceived. It is how things or persons are seen, imaged, or pictured. Gender portrayals refer to the varied ways that men and women are seen, described and affirmed in society. Attitude to men and women is based on the notions, ideals, and beliefs about men and women in society. The way men and women are portrayed is rooted in gender discrimination.

The concern here is with gender portrayal in Urhobo traditional music. The term Urhobo can be used to describe both the people and the culture. The Urhobo people live in Nigeria's Niger Delta in the present Delta State. The word, traditional will be used here to refer to indigenous, coming from Urhobo land from ancient times. It is not imported into Urhobo land. This does not deny the fact today that what is traditional is now often influenced by other external cultures. In this work, the phrase Urhobo traditional music will be used to describe the indigenous music produced by the Urhobo people. By extension, it can be the music of people of Urhobo ancestry or even by non-Urhobo persons that deals with issues relevant to Urhobo people and culture produced in the Urhobo language.

\section{The Challenge of Feminist Ethics}

There are a lot of challenges that feminist ethics poses for culture and society in Africa, and Nigeria in particular. The fundamental challenge is the call to gender equality and equity. Men and women are created ontologically equal. They should be treated as equals. It does not mean they perform or play the same roles in society. It is women who bear children in their womb before they are given birth. But biological-sexual differentiations do not amount to inequalities. This is the mistake that many ancient cultures in Africa made and from this, they produced discriminatory practices that subjugate women. The pain is that today many of those discriminatory practices are still there.

Another important issue that feminist ethics has highlighted is the issue of patriarchy. This is at the root of the atrocities committed against women, children, and at times men. Patriarchy is the rule of fathers. Fathers are male. It comes from the Latin word, Patria meaning father. In itself, there may be nothing wrong with the father's ruling. But the fact is that leadership should be a shared responsibility and collaborative issue. The reality is that the rule of men or fathers is premised on the wrong notion or assumption that it is the divine order and they are created to rule by dominating. They are perceived to be given authority by the gods. Almost all religions unfortunately have endorsed this notion that men are more endowed and can think better than women. Men and women are indoctrinated and groomed to believe and accept that the role of the woman is to submit without question even when they are denied fundamental basic rights that all people should be entitled to. Women are to be seen not to be heard. They have no right to challenge men. It is notions like these that feminist ethics questions and challenges. Women are said to have no voice. Even in decisions that affect them they have no contribution to make.

When it comes to the issue of employment, women often are more disadvantaged than men. Work and labour are major issues in human life. Men and women can do equal jobs but they are paid differently. The British Council (2012) indicated that:

$54 \%$ of Nigerians still live-in poverty and the proportion has doubled since 1980 (when about $28 \%$ were classified as poor). Nigeria's human development indicators are also worse than those of comparable lower middle-income countries. $42 \%$ of Nigerian children are malnourished. The averages hide a context that is worse for women and girls. Nearly six million young women and men enter the labour market each year but only $10 \%$ are able to secure a job in the formal sector, and just one third of these are women. 
The above suffices to describe the challenge of feminist ethics. The important thing to note about feminism is that it calls for recognition of the dignity and value of women and children and the need to treat them as equal to men. It also emphasizes the need to promote all human rights and give them to women also.

\section{GENDER PORTRAYALS IN URHOBO TRADITIONAL THOUGHT AND CULTURE}

Aziza (2003) notes that: "In Traditional Africa culture, the woman is spared difficult jobs such as felling of trees or climbing trees, e.g., to cut palm fruit from palm trees, etc. Such jobs are reserved for the man while the woman busies herself with the less strenuous concerns of daily life and living." This perception of women and men as she notes comes from the fact that women are considered to be soft, gentle, tender, tolerant and peaceful; while men are considered to be rugged and strong. It should be noted right away that some feminist scholars will not agree with this perception of the qualities of the woman as a society has often used these so-called qualities to limit women and confined them to domestic roles. Some feminist scholars will argue that the roles and even qualities assigned to men and women are often sociological and cultural and do not arise from their biological make-up.

Writing further of Urhobo culture, Aziza (2003) avers as follows:

However, although the woman is supposed to complement the man and together they represent the totality of God's creation, traditional societies the world over are dominated by men. The men are the decision makers and the definers of roles in society, and of course, they define the roles in their favour. The birth of a son is often heralded with pomp and pageantry and from the first day of his life he is treated as special. On the contrary, many homes have either been broken or become polygamous because the woman is accused of bringing forth only girls.

Urhobo culture in terms of perception of the role of women and men is not different from other African cultures. The paper agrees with Aziza (2003) that in time past the girl-child was deprived of equal educational opportunity, the girl-child was seen as another man's child as she will get married and leave the house, the woman is not expected to be self-assertive or psychologically developed, she is not allowed to partake in major decisions even when they affect her, she is deprived of inheritance when her husband dies even when she contributed to the man's projects, she is called a witch if her husband is unsuccessful and she is not speaking.

As like most of Africa, Urhobo society is generally patriarchal, men exercise authority which often goes unquestioned by women and children and women are to do the bidding of men. Of Urhobo culture, Otite (1991) writes thus:

A man is the head of the family within which he maintains his authority. A wife defers to her husband. Traditionally, she serves food to the husband and his visitors, if any, but does not eat with them; instead, she stands by, outside the door, waiting to be called for anything, she never eats with her husband. She also serves hot water for bathing and waits outside within distance. She never strolls with her husband; if both must attend a ceremony anywhere, they either go at different times or one goes in front of the other, less than a pole apart. (p. 39)

In all dimensions of life in Urhobo men and boys are privileged over women. Gender relations are structured in favour of the progress and success of men. A little boy is considered more elderly than the woman who has married into the family and the woman is expected to pay reverence to the little boy even kneeling to serve the boy. Erhimeyoma (2016) cites Jike who notes that: "the male siblings within the family, whether junior or senior, take charge of control over the girls. Males determine the general policies relating to finance, security, and even have a say or approval on the relationships that the girls can keep within the parameters of the society" (p. 86).

The fact is that men, even young boys were held in high esteem and given prominent places in society. The woman or the girl-child was seen as lower than a human being very often. In Urhobo culture as in many other African cultures, men are considered to be stronger and superior to women. Women are perceived as inferior and the weaker sex. They are

4 | This work is licensed under a Creative Commons Attribution 4.0 International License. 
often confined to domestic chores such as cooking, fetching water, taking care of the home, caring for the children, etc. They can be allowed to do some agricultural works such as clearing and cultivating cassava and other food crops, fish farming, etc. Because they are perceived to be weaker, they are not allowed to climb trees, go hunting for wild animals and going to the war front. Male children can accompany their fathers to go to the forest to hunt as they grew up but never the female children.

They were considered not to be as intelligent as men. It is unfortunate to note that emphasis was not laid on the education of the female child. Parents invested in the education of their male children when western education, came to the detriment of the females. The female child was considered to eventually get married and has no contribution as such to provide for her family. Her new family is now the marital family.

\section{Gender Portrayals in Urhobo Traditional Music}

That music plays a prominent place in human culture is hardly disputed. In the philosophical literature, prominent philosophers have enunciated the significance of music. It should be noted that cultural portrayals of gender and perceptions are not stagnant. Urhobo culture and tradition as other cultures are experiencing transition and change. It is impacted today by both the forces of westernization, modernity, and globalization. Even as you listen to Urhobo music you see some Urhobo musicians noting this change and transition. While some agree with the change and progress, some others do not. Noting this issue of change, Aziza (2003) quotes a song from Chief Johnson Adjan thus:

\section{Oke rawanre ru me yere wan $e-e$ \\ Eshare da wan nu eya me kekako e -e \\ Oroke nana ru me yeri vwa e-e \\ Eya doda me ayen ji. Dineme $e-e$ \\ Oshare rerhi me mi kese ruona re e}

Aziza (2003) a foremost scholar on Urhobo issues interprets this song thus-in time past men bought cutlass and cleared the bush, while women did only the planting of crops. But today women are buying cutlasses and clearing the bush and working for themselves and are no longer docile sex symbols.

Below are five songs by some Urbobo musicians.

\begin{tabular}{|c|c|c|}
\hline Songs in Urhobo Language & English Translation & Analysis and Implications \\
\hline $\begin{array}{l}\text { Emete rinajiria } \\
\text { Edekpota re omote vwe } \\
\text { awanre } \\
\text { Ose re omote koye bre ra } \\
\text { Oroke nana rosherhe } \\
\text { Emete ravwanre vwoma bro } \\
\text { ogo obe eko } \\
\text { Emete rinajiria vwoma rue } \\
\text { iprishi eti ne na. }\end{array}$ & $\begin{array}{l}\text { Daughters of Nigeria } \\
\text { In ancient times when seeking the } \\
\text { hand of a girl in marriage } \\
\text { We approach the girl's parents } \\
\text { But, in our present time, our } \\
\text { daughters/Girls have given } \\
\text { themselves sheepishly in marriage } \\
\text { in Lagos } \\
\text { Our girls are now like witness } \\
\text { members moving all about giving } \\
\text { themselves free of charge. }\end{array}$ & $\begin{array}{l}\text { The songs describe Nigerian girls } \\
\text { as being influenced by modern- } \\
\text { day trends. They are described as } \\
\text { sheepish for giving themselves in } \\
\text { marriage in the city of Lagos } \\
\text { without the consent of their father. } \\
\text { It is very rare to see girls who give } \\
\text { themselves in marriage without } \\
\text { any form of approval from their } \\
\text { parents. Implicit in the song is the } \\
\text { idea that all the affairs that affect } \\
\text { the girl are to be controlled by the } \\
\text { male father. Guys who may take } \\
\text { decisions to marry in Lagos are not } \\
\text { equally critiqued by the musicians. }\end{array}$ \\
\hline $\begin{array}{l}\text { Aye ro guono ophrophro re } \\
\text { Gbe no oronvwe } \\
\text { Oni rovwiewe ovwiewe } \\
\text { nurhe } \\
\text { Oghare ke oromo } \\
\text { Ode wenwen wo mi chuji }\end{array}$ & $\begin{array}{l}\text { A woman/wife who detests mate } \\
\text { Should leave the marriage } \\
\text { Your mother has given birth to you } \\
\text { Destiny is no yours [child] } \\
\text { If you like steal from people } \\
\text { If you like, take to prostitution }\end{array}$ & $\begin{array}{l}\text { The woman who does not want his } \\
\text { husband to marry a second wife or } \\
\text { other wives should leave the } \\
\text { marriage. The idea presented here } \\
\text { is that men have unbridled and } \\
\text { unlimited rights to marry as many }\end{array}$ \\
\hline
\end{tabular}

5 | This work is licensed under a Creative Commons Attribution 4.0 International License. 


\begin{tabular}{|c|c|c|}
\hline Songs in Urhobo Language & English Translation & Analysis and Implications \\
\hline $\begin{array}{l}\text { Ode wenwe mi gbe ofarhien } \\
\text { Ode wowen wo mi yono ebe } \\
\text { Ode wowen wo mi vwaerhan } \\
\text { Ode wowen wo mi phiwayo } \\
\text { Ose ro vwiewe vwiewe nure } \\
\text { Ose we ken okor igho } \\
\text { Oda ra reye oni wen rhe } \\
\text { Oni wen da rhe mrevu,ode } \\
\text { vwiewe } \\
\text { Ovwie we nu ofarhien koyi } \\
\text { wo gbe } \\
\text { Ovwie we nu ke uji wo cho } \\
\text { Ovwie we nu ozighi koye wo } \\
\text { gbe } \\
\text { Agba rha hanrhe Ese ve ini } \\
\text { Oghare ke oromo } \\
\text { Ede bre omo uche ko reyo }\end{array}$ & $\begin{array}{l}\text { If you like, be serious with } \\
\text { education } \\
\text { If you like, practice wizardry } \\
\text { If you like, practice native doctor } \\
\text { If you like, practice cheating [419] } \\
\text { Your parents have given birth to } \\
\text { you } \\
\text { Your father gathers money } \\
\text { And took your mother as a wife } \\
\text { Your mother became pregnant and } \\
\text { gave birth to you } \\
\text { Having given birth to you, you } \\
\text { started prostitution } \\
\text { Having giving birth to you, you } \\
\text { started stealing } \\
\text { Having giving birth to you, you } \\
\text { became a rascal } \\
\text { We should stop blaming parents } \\
\text { Destiny belongs to the child }\end{array}$ & $\begin{array}{l}\text { women as they like even without } \\
\text { consulting with their present wife. } \\
\text { Religious teachings on polygamy } \\
\text { will not be the concern here after } \\
\text { some religions permit polygamy } \\
\text { while others do not. The concern } \\
\text { here is with the fact that the } \\
\text { woman is excluded from the } \\
\text { decision-making process in a } \\
\text { crucial issue that will affect her. } \\
\text { Her experience, knowledge, } \\
\text { challenges and what it will take to } \\
\text { live with another woman married } \\
\text { to the same man is not even given } \\
\text { a thought. The man is the decision- } \\
\text { taker. The culture presents the } \\
\text { view and position of the woman as } \\
\text { the only one that matters in this } \\
\text { issue. The many negative } \\
\text { challenges that come with } \\
\text { polygamy are not even reflected } \\
\text { upon collectively by the husband } \\
\text { and wife, as the wife has no say. }\end{array}$ \\
\hline $\begin{array}{l}\text { Aye me nuvwe obo } \\
\text { Mini mi kere emu } \\
\text { Kitivo mi kere te } \\
\text { Ose re aye me ghwuru mi } \\
\text { shiro } \\
\text { Oni re aye me ghwuru mi } \\
\text { shiro } \\
\text { Emuroye kitivo mi kere te }\end{array}$ & $\begin{array}{l}\text { My wife left me [marriage] } \\
\text { I decided to take back the bride } \\
\text { price } \\
\text { Where do I start the stock of } \\
\text { expenses? } \\
\text { I buried her father [in-law } \\
\text { greetings] } \\
\text { I buried her mother [in-law } \\
\text { greetings] } \\
\text { All for her, where shall I start } \\
\text { from? }\end{array}$ & $\begin{array}{l}\text { The musician presents a man } \\
\text { lamenting that his wife has left him } \\
\text { after all he has invested in the wife } \\
\text { and her family. The man thinks } \\
\text { that if he takes his bride price back, } \\
\text { it is not even enough for all his } \\
\text { investment. The interest of the } \\
\text { woman and all that she has } \\
\text { contributed to the man are not } \\
\text { taken into consideration. The man } \\
\text { thinks only of his money and his } \\
\text { interests. The woman is perceived } \\
\text { as property by the man and the } \\
\text { woman is to serve him no matter } \\
\text { what the man does. Notions like } \\
\text { this are what the feminists quarrel } \\
\text { with. }\end{array}$ \\
\hline $\begin{array}{l}\text { Emete re oke na } \\
\text { Kirhi muogho kewe [oshare] } \\
\text { Je igho/idolo rhewe } \\
\text { Aye re ogbere sere oderhi } \\
\text { Aye re odafe ghrenghren } \\
\text { Osono hwe orive }\end{array}$ & $\begin{array}{l}\text { Modern girls } \\
\text { Before they will respect/honour } \\
\text { your husband [man] } \\
\text { Know there is sufficient money in } \\
\text { your possession [pocket] } \\
\text { While the poor man's wife calls } \\
\text { her husband by his name }\end{array}$ & $\begin{array}{l}\text { The woman is presented as if she } \\
\text { is the only one who is to love, } \\
\text { respect and honour the } \\
\text { man/husband. The obligation to } \\
\text { love, respect and honour should be } \\
\text { mutual in marriage. While it is true } \\
\text { that some women do not respect } \\
\text { their husbands if they are poor; the } \\
\text { maltreatment that some women }\end{array}$ \\
\hline
\end{tabular}

6 | This work is licensed under a Creative Commons Attribution 4.0 International License. 


\begin{tabular}{|l|l|l|}
\hline Songs in Urhobo Language & English Translation & Analysis and Implications \\
\hline & $\begin{array}{l}\text { The rich man's wife is honoury } \\
\text { cher husband's name with good } \\
\text { attributes } \\
\text { It is a pitiable circumstance }\end{array}$ & $\begin{array}{l}\text { suffer from their rich husbands } \\
\text { should also be critiqued. The } \\
\text { danger very often is that men are } \\
\text { given a loose rope to misbehave } \\
\text { and often unquestioned in Urhobo } \\
\text { culture. }\end{array}$ \\
\hline
\end{tabular}

An essential aspect of Urhobo culture as in other African cultures is marriage. There are procedures and processes in Urhobo culture. Depending on the brand of feminism that one subscribes to, one consequence of feminisms can be the dethronement of every form of authority. Male patriarchal authority is often questioned by feminists. This present author sees nothing wrong with male patriarchal authority as far as it works for the good ordering of the family and for justice. Authority is for service. Authority is equally collaborative and should be cooperative. Urhobo music can function as a critique of some excesses of western influence rooted in radical feminist thinking. Many Urhobo songs on the role and duties of men and women, wives and husbands are often biased and prejudiced against women and the female. Men can fail and misbehave in marriage and family life and they go unquestioned. Because of the undue privilege given to men by this male patriarchal culture, men often engage in wife battery, domestic violence and other abuses against women.

Aziza (2013) cites Chief Omokomoko Osokpa, who is considered to be the father of Urhobo music singing: "Aye komo rohwofa me mrere vughe" meaning "I have realized that a woman is someone else's child." The fact is that the way the woman is presented in Urhobo culture and music is unjust and leaves much to be desired. The point needs to be made in the light of feminism that the female has fundamental human rights like the male. The female should not be deprived of the rights to inheritance, residence, decision making, etc because she is a woman. Akusu critiques the maltreatment of a woman who has suffered from a failed marriage, etc and has returned to her paternal compound in her presentation in $O g b e$. She says:

Family home base for married women/wife who return from marriage.

A base for the male child

A woman/wife may decide to retire home at old age or at the death of her husband

Or when she decides not to marry again

At that time such a person is the term omotogbe.

She should be allowed to come back home and not discriminated against by the males in the family compound

The females have rights in their father's compound as the males and should not be discriminated against. She should not be insulted and maligned for returning back home if her marriage has been unfavorable. In Urhobo culture, the woman who returns from marriage even due to no fault of her room is discriminated against. At times she is not even given a place to live in her father's compound. It is wrongly believed that through marriage she has been "sold" away.

\section{Rethinking and Reconstructing Gender Portrayal with Feminist Ethics}

There is a vital need to rethink and reconstruct gender portrayal in Urhobo culture, and African culture in general. The way gender is portrayed that has led to discrimination and oppressive practices against women are not acceptable. Some of the challenges that feminist ethics poses for gender portrayal have been enumerated above. How should feminist ethics reconstruct gender portrayal? The

7 | This work is licensed under a Creative Commons Attribution 4.0 International License. 
viewpoints of some feminist ethicists and philosophers are presented below.

The call for affirming equality among men and women in Africa as feminists ethics will propose is not totally strange to Africa. African traditional thought is rooted in an ethics of communalism, solidarity, ubuntu, ukama, and togetherness. All things are interrelated in one community and web of life. Women and men are interrelated and their contributions are necessary for the building of society. The contribution of women is not inferior to that of men. The dictum of ubuntu-I am because we are- applies to both men and women. Men are incomplete with women. Erhimeyoma (2016) rightly indicates that: "a human being is not considered a person solely on account of herself or himself. This, it is generally agreed upon by African philosophical scholars..." (p. 67). Scholars such as Mbiti, Metz \& Gaie (2010), Wingo (2017), Gyeke (2015) are all in support of this idea. The fact is that the African notion of humanity, personhood, and communalism can help repair gender relationships.

There is a need for positive images and portrayals of the role of women not negative images. Women should not be described in Urhobo music as if their opinions are not needed in issues affecting marriage and family life. Their opinions are vital and count. Urhobo musicians should create songs that emphasize the positive role of women. Feminist ethics can help in reconstructing gender portrays in Urhobo music through the following means: (1) radical critique of the negative gender images in western philosophy which has equally affected African culture, (2) promoting just gender education, (3) supporting women empowerment and liberation, (4) synthesizing positive values from the various kinds of feminisms and using them to conscientize African people, (5) emphasizing the fundamental rights of persons.

Feminist ethics is a sub-branch of philosophy. Apart from few positive notions of women in western philosophy, the western philosophical enterprise has had a negative perception of women. Philosophers such as Aristotle, and Hegel had negative views of women. For Aristotle (1984) men are to rule over women and they lack the ability to hold authority. For Hegel (1967) women lack the ability required in the advanced sciences and philosophy as they cannot reach the ideal and as there is so much difference between plants and animals so there is between men and women. In his exact words, as cited by Witt \& Shapiro (2017), Hegel says: "Women are capable of education, but they are not made for activities which demand a universal faculty such as the more advanced sciences, philosophy and certain forms of artistic production. ... Women regulate their actions not by the demands of universality, but by arbitrary inclinations and opinions." Witt \& Shapiro (2017) also notes that Plato and Kant saw women as inferior to men. Kant saw women as inferior to men as they lack authentic moral motivation.

Very often African students of philosophy are not given room to critique these viewpoints, thus these negative viewpoints corroborate what their culture already affirms and thus the negative portrayal of women continues. Feminist ethics arose in part to critique the western enterprise of philosophy.

With regard to Urhobo music women experience and realities, and their ways of knowing should feature more prominently. This can happen in the following ways: more Urhobo women musicians coming into the Urhobo music industry, and Urhobo music informed by positive ideas on both the place of men and women in society.

There are positive ideas from various forms of feminism that can inform the ideas of Urhobo musicians and scholars. Various forms of feminism include humanist feminism, radical feminism, socialist feminism. Humanist feminism affirms that men and women are humans and deserve equal rights, it is a male-patriarchal society that had oppressed women by denying them universal human rights. Both Wollstonecraft (1988) and Mill \& Mill (1970) object to depriving women of fundamental human rights. With the coming of the United Nations (1948) Universal Declaration of Human Rights, it is untenable to deprive women of fundamental basic rights that should be accruable to both men and women. There is the basis to critique any form of Urhobo music that portrays women as inferior and men as stronger or that portrays women as simply to be subservient. These positive ideas have to be promoted through positive and just gender education. If these ideas are not made known they will not be known. 
It should be noted that this paper does not in any way imply that feminism had no limitations or negative aspects. But that is not the concern here. It will suffice to just not briefly some of these limitations, It is often informed by ideas of western feminist scholars that may not pay much attention to the African situation. In Clement (2013), “just as male philosophers have taken themselves as representative of humanity, so too some feminists have inadvertently taken white, middle-class, heterosexual Western women to be representative of all women" (p. 1926).

It can go into extreme criticism of all of the African culture without paying attention to the fact that there were African societies in which women are treated equally and given a prominent place in society. This paper notes that this so-called positive view of women is a rare exception. And so there is still room to radically critique African culture and portrayal of gender in Urhobo music. In reconstructing gender portrayals in Urhobo music and culture, the ethics of equal regard proposed by Browning (2013) is helpful. He states that it implies mutual respect not just in the Kantian way, striving for the good and advancement of the other and sacrifice for the other. Men and women need to live by an ethic of equal regard in marriage and the family.

\section{CONCLUSION}

The central point of this paper is that some Urhobo music has negatively portrayed women in their music while privileging the authority of men. These kinds of music promote patriarchal notions of family and marriage that discriminate against women and oppress. The paper has shown that in the light of contemporary feminist ethics there is a need to reconstruct such kinds of Urhobo music. This can be done by paying particular attention to the positive ideas from feminist ethics while being critical of negative aspects.

Doing this reconstruction requires a great deal of gender education and conscientization in the philosophy classroom, music classroom and among Urhobo musicians. If Urhobo culture and thought can be transformed in the light of positive values from feminist ethics, it will help to make develop a better relationship with women and create a better society.

\section{REFERENCES}

Aristotle. (1984). The Politics, trans. Carnes Lord. Chicago: University of Chicago Press.

Aziza, R.O. (2003). Women and Leadership in Urhoboland: The Language Dimension http://www.waado.org/urhobo_kinsfolk/archive /conferences/fourth_annual/academic_papers/W omen-Aziza.html

British Council Nigeria. (2012). Gender in Nigeria report 2012 improving the lives of girls and women in nigeria, https://www.britishcouncil.o $\mathrm{rg} /$ sites/default/files/british-council-gendernigeria2012.pdf

Browning, D. (2013). Introduction: The equal regard family in context. In Amy Wheeler

John Witte Jr. M. Christian Green (Eds.), The Equal-Regard Family and Its Friendly Critics. Grand Rapids, MI: Eerdmans Publishing Company.

Gyeke, K. (2015). An Essay on African Philosophical Thought: The Akan Conceptual Scheme. https://www.temple.edu/tempress/titles /1241_reg_print.html

Erhimeyoma, E. E. (2016). Rethinking the Nigerian family system. Ibadan: Kraft Books Limited.

Hegel, G.W.F. (1967). Hegel's Philosophy of Rights, trans. T.M. Knox. Oxford: Oxford University Press.

Johari, J.C. (2012). Contemporary political theory: New dimensions, basic concepts and moral trends. New Delhi: Sterling Publishers Pvt Limited.

Menon, N. (2008). Gender. In R Bhargava \& A Acharya (ed)., Political Theory: An introduction, pp.224-233. New Delhi: Pearson.

Metz, T. \& J Gaie, J.R.B. (2010). The African ethic of Ubuntu/Botho: implications for research on morality. Journal of Moral Education. Volume 39, 2010 - Issue 3: Moral Education in subSaharan Africa - Culture, Economics, Conflict and AIDShttp://dx.doi.org/10.1080/03057240.2 010.497609 .

9 | This work is licensed under a Creative Commons Attribution 4.0 International License. 
Mill, J.S., \& Mill, H.T. (1970). Essays on sex equality, ed. Alice Rossi. Chicago: University of Chicago Press.

Otite, O. (1991). Marriage and family systems in Nigeria. International Journal of Sociology of Family, 21, no 2 (39). Accessed on 3 October 2017, from https://www.jstor.org/stable/230298 11 ?seq=1\#page_scan_tab_contents

United Nations. (1948). The Universal Declaration on Human Rights. http://www.un.org/en/univer sal-declaration-human-rights/

Witt, Charlotte and Shapiro, Lisa, "Feminist History of Philosophy", The Stanford Encyclopedia of Philosophy (Spring 2017 Edition), Edward N. Zalta (ed.), URL $=\langle$ https://plato.stanford.edu/a rchives/spr2017/entries/feminism-femhist/>.

Wingo, Ajume, "Akan Philosophy of the Person", The Stanford Encyclopedia of Philosophy (Summer 2017 Edition), Edward N. Zalta (ed.), URL $=<$ https://plato.stanford.edu/a rchives/sum2017/entries/akan-person/>.

Wollstonecraft, M. (1988). A vindication of the rights of woman. New York: Dover.

10 This work is licensed under a Creative Commons Attribution 4.0 International License. 